\title{
Heat Treatment of Basalt Fiber Reinforced Expanded Clay Concrete with Increased Strength for Cast-In-Situ Construction
}

\author{
Makhmud Kharun $^{1}$, Sergey Klyuev ${ }^{2}{ }^{(0}$, Dmitry Koroteev $\left.{ }^{1}{ }^{(}\right)$, Paschal C. Chiadighikaobi ${ }^{3}{ }^{(1)}$, \\ Roman Fediuk $^{4, *}$, Andrej Olisov ${ }^{5}$, Nikolai Vatin ${ }^{6}(\mathbb{D}$ and Nataliya Alfimova 2,5 (D) \\ 1 Department of Civil Engineering, Peoples' Friendship University of Russia (RUDN University), 6 Miklukho \\ Maklaya Street, 117198 Moscow, Russia; miharun@mail.ru (M.K.); koroteev_dd@rudn.university (D.K.) \\ 2 Department of Theoretical Mechanics and Strength of Materials, Belgorod State Technological University \\ named after V.G. Shukhov, 308012 Belgorod, Russia; Klyuyev@yandex.ru (S.K.); alfimovan@mail.ru (N.A.) \\ 3 Pacherozi Engineering and Materials, 14 Chief Andy Obidike Lane, 440001 Osisioma Aba, Abia State, \\ Nigeria; passydking2@mail.ru \\ 4 Polytechnical Institute, Far Eastern Federal University, 690922 Vladivostok, Russia \\ 5 Additive Technology Center, National Research Tomsk State University, 634050 Tomsk, Russia; kobis@bk.ru \\ 6 Higher School of Industrial, Civil and Road Construction, Peter the Great St. Petersburg Polytechnic \\ University, 195251 St. Petersburg, Russia; vatin@mail.ru \\ * Correspondence: roman44@yandex.ru
}

Received: 8 October 2020; Accepted: 30 October 2020; Published: 2 November 2020

\begin{abstract}
Expanded clay concrete (ECC) is a promising structural material for buildings due to its light weight and heat- and sound-insulating properties. Adding basalt fibers (BFs) in ECC reduces its brittleness and enhances its mechanical properties. The heat treatment (HT) of BF-reinforced ECC can significantly accelerate the strength growth during cast-in-situ construction, which allows the reduction of the turnover of the formwork and the construction period, as well as leading to lower construction costs. This paper presents an HT technology for load-bearing structures, containing a BF-reinforced ECC mix and using infrared rays for cast-in-situ construction. The issue of the strength growth of BF-reinforced ECC during HT has been studied. Microsilica and fly ash were added to the ECC mix to obtain a compressive strength of more than $20 \mathrm{MPa}$. Four different mixes of ECC with chopped BFs in the ratios of 1:0, 1:0.0045, 1:0.009 and 1:0.012 by weight of cement were studied. Test specimens were heated by infrared rays for $7,9,11,13,16$ and $24 \mathrm{~h}$. Then, the heat-treated specimens were tested for compressive strength after $0.5,4,12$ and $24 \mathrm{~h}$ cooling periods. The analysis and evaluation of the experimental data were carried out based on probability theory and mathematical statistics. Mathematical models are proposed for forecasting the strength growth of BF-reinforced ECC during cast-in-situ construction.
\end{abstract}

Keywords: expanded clay concrete; basalt fiber; compressive strength; heat treatment; infrared ray; cast-in-situ construction; curing period

\section{Introduction}

Expanded clay concrete (ECC) is one of the lightweight concretes that has the greatest heat and sound insulating properties, which gives it a significant position in the construction industry [1-4]. However, due to its brittleness and low strength it cannot be used in load bearing structures [5-7]. Recently, basalt fibers (BF) have gained popularity in concrete reinforcing due to their thermal resistance, chemical resistance, environmental friendliness and good mechanical characteristics [6-10], and the addition of BF in ECC reduces its brittleness and increases strength [8,9]. Over the past 
decade, many studies have been carried out on the physical and mechanical properties of BF-reinforced concrete. Some studies [10-13] have revealed that BF can significantly improve the flexural properties of concrete. BF in concrete prevents cracks in it by reducing the magnitude of free shrinkage and by restricting crack growths if they occur [14-17].

As proved earlier, one of the most effective ways to increase the aggregate stability of lightweight concrete mixtures, as well as to improve their structure formation, is reinforcement with dispersed fibers [1,2]. At the same time, there is a decrease in shrinkage deformations by several times, which significantly improves the operational properties of dispersed-reinforced expanded clay concrete.

With all the advantages of fiber-reinforced ECC, this material has been rather insignificantly studied for concreting conditions at negative temperatures. The execution of construction work in various climatic conditions while striving to reduce construction time contributes to the development of innovative technologies for monolithic construction. The necessity for year-round construction works leads to an increase in the volume of winter concreting, especially when the average daily ambient temperature is below $+5{ }^{\circ} \mathrm{C}$ and the minimum daily temperature is below $0{ }^{\circ} \mathrm{C}$. This is particularly important for the climatic conditions of Russia, Finland, Sweden, Norway and Canada where the cold season lasts more than six months in a year.

In the cold season, the curing rate and the quality of the concrete is reduced due to the cyclic processes of freezing and thawing [18-22]. These situations create some specific threats to building structures that are made without special technological measures that regulate the temperature of the freshly laid concrete mix.

During cast-in-situ construction, a significant amount of time is spent waiting for the growth of the strength of the concrete slab. After dismantling the forms from the casted slab, all its supporting stands must be kept until the concrete strength reaches at least $50 \%$ of the designed (R28). Upon reaching $50 \%$ of the designed strength of concrete, half of the supporting stands should be kept, and at $70-80 \%$ of the designed strength, one fifth of the supporting stands are kept. In order to reduce the construction period and turnover of the formwork, as well as the construction costs, it seems appropriate to reduce the required setting time of concrete.

In some cases, chlorides and nitrates are used in concrete mixes as antifreeze additives, which have the properties of electrolytes when dissolved in water [18-22]. Due to the strong corrosive effects on metals and building structures, as well as the negative influence on the environment, chlorides and nitrates are not recommended by some scholars [23-26].

The most widely used methods of winter concreting are heat treatment (HT) in a heated formwork, induction heating, concreting in warm tents, steam heating, etc. [15,16]. Some researchers $[15,16,18,19]$ have developed various technologies for winter concreting, which allow one to optimize construction works by selecting the most widely used methods for cast-in-situ construction.

Studies of the effect of HT on high strength concrete indicated that early HT initiated a high early strength $[24,25]$; however, HT at $120^{\circ} \mathrm{C}$ on high density concrete resulted in a large loss of moisture from concrete [26]. A study of the effect of $\mathrm{HT}$ at a maximum temperature of $60^{\circ} \mathrm{C}$ on self-compacting concrete showed an overall gain in strength at an early age [27].

A study of the radio wave technology for HT of concrete showed a uniform energy supply at distinct rates under a stable closed-loop temperature control; however, at a temperature above $60{ }^{\circ} \mathrm{C}$, ettringite formation slowed down [24]. Studies of the effect of HT on the physical and mechanical properties of recycled aggregate concrete while using different treatment methods evaluated that HT was the most effective treatment method in improving strength; however, a rehydration effect was observed [28,29]. It should be noted that the optimum temperature for HT of concrete is $80-95^{\circ} \mathrm{C}$; otherwise, evaporation of moisture from the laid and compacted concrete mix may occur [30-33].

One of the most efficient methods for HT of concrete is its infrared heating using gas or electric emitters. The disadvantage of infrared heating using gas burners is the necessity to create an enclosed area in the form of a shelter-tent to protect gas burners from being blown by the wind, which increases 
the complexity of its implementation. This situation prevents the widespread use of HT of laid and compacted concrete using gas burners.

The advantage of HT technology for a laid and compacted concrete mix with infrared rays using electric emitters and a two-chamber polyethylene-terephthalate membrane cover is the possibility of heating the fresh concrete mix without re-equipping the appliance, since infrared emitters are mobile and can be installed in any convenient location.

The analysis of scientific and technical publications shows that many studies have been dedicated to HT of concrete, which can be executed in construction work during the cold season. A number of technologies for HT of concrete structures were proposed by different scholars [30-33]; however, all of these technologies are associated with high electrical energy costs, and solutions for HT of load bearing structures with BF-reinforced ECC for cast-in-situ construction are not proposed.

In cast-in-situ slab constructions, due to the pretty slow growth of concrete strength, the formwork and the supporting stands should be kept for up to three weeks depending on weather conditions. This situation complicates the production of other works and significantly increases the volume of the formwork, therefore leading to an increase in the construction period and an increase in the cost of building.

The technology for HT of laid and compacted concrete mixes using infrared rays using gas burner and two-chamber transparent covers [34] provides the conditions for the normal course of the chemical reaction of hydration, curing and strength development of concrete. HT by infrared rays allows about $70 \%$ of the design strength of concrete to be achieved in a 24-h cycle [34]. The advantage of this technology lies in the possibility of heating fresh concrete without re-equipment of the infrared appliance, since it is mobile and can be installed in any convenient place. However, the disadvantage of infrared heating using gas burners is the necessity to create an enclosed space in the form of a tent to protect the gas burners from wind, which increases the complexity of its execution.

Even though a lot of studies have been done on winter concreting, the technical significance of the problem is extensive and requires additional study. This publication aims to propose an HT technology for load bearing structures with BF-reinforced ECC for cast-in-situ construction using infrared rays, which allows one to ensure conditions for the normal course of the chemical reaction of curing and strength growth, and also to present the result of studying the issue of the strength growth of BF-reinforced ECC during HT.

\section{Technology of Heat Treatment}

One of the conditions for obtaining high-quality cast-in-situ structures is the creation of a favorable environment in the early stages of curing. Precast Concrete Plants usually conduct a thermal-humid treatment of concrete to ensure the rapid gaining of concrete strength. The thermal-humid treatment process usually consists of the following operational steps [34]:

Step 1. Keeping cast products in the formwork for about $2-3 \mathrm{~h}$.

Step 2. Placing these formed products into a thermal-humid chamber, and raising the temperature in the thermal chamber up to a constant maximum of $80-95^{\circ} \mathrm{C}$ for about $1 \mathrm{~h}$.

Step 3. Isothermal heating in the thermal-humid chamber at a maximum calculated temperature of $80-95^{\circ} \mathrm{C}$ for about $6-10 \mathrm{~h}$.

Step 4 . Reducing the temperature in the thermal-humid chamber within $2-3 \mathrm{~h}$.

The total duration of the entire process is 12 to $17 \mathrm{~h}$. Depending on the overall cycle time, the strength of concrete after HT reaches 45 to $75 \%$ of the designed strength.

In cast-in-situ construction, in most cases, HT of the laid and compacted concrete mix is only carried out at freezing ambient temperatures.

Some studies of HT of the laid and compacted concrete mix were carried out in the construction materials laboratory of the RUDN University, which worked out a new technology of HT of the laid and compacted concrete mix in load bearing structures, including structures with BF-reinforced ECC, 
during cast-in-situ construction. The layout of HT of a slab with BF-reinforced ECC using infrared rays for cast-in-situ construction in frosty weather is shown in Figure 1.

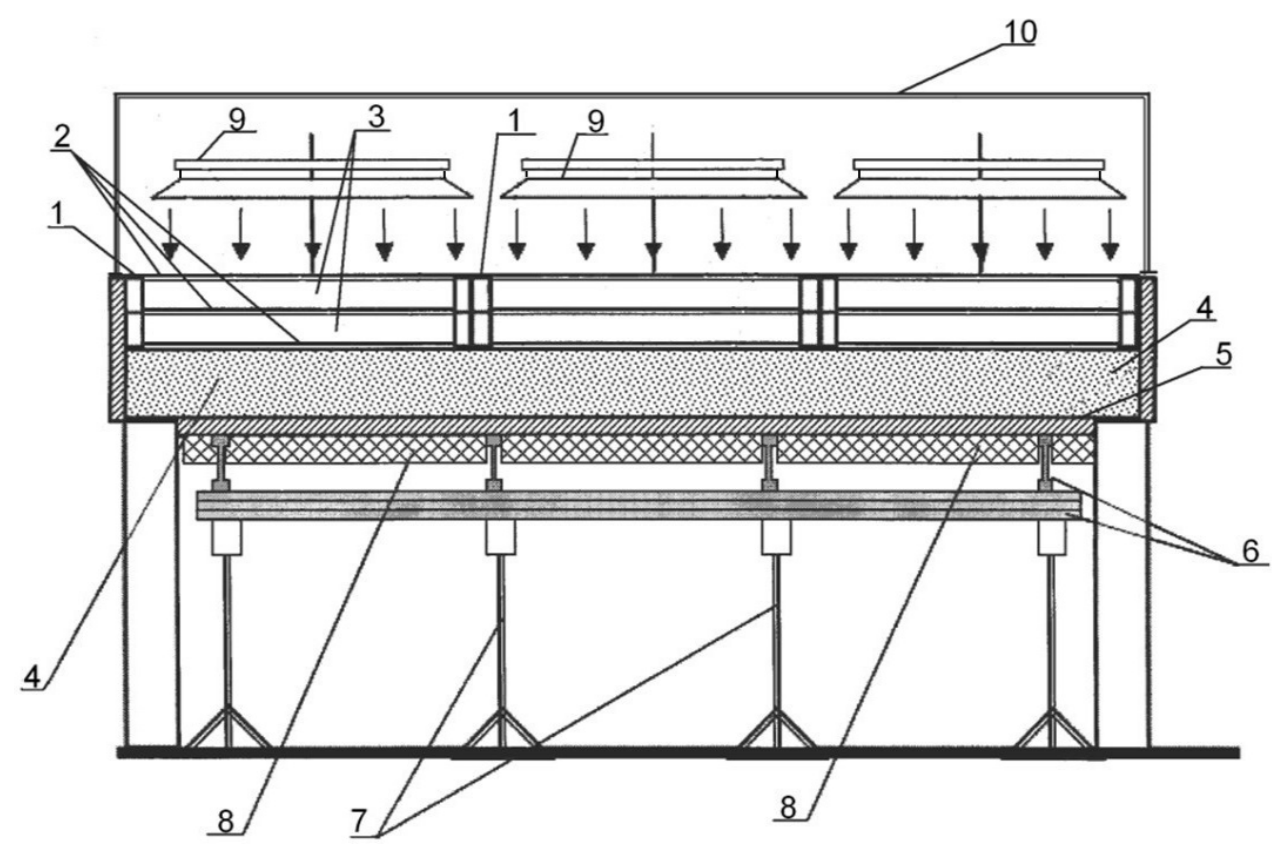

Figure 1. Layout of HT of a slab with BF-reinforced ECC using infrared rays for cast-in-situ construction in frosty weather: 1-clamps for fixing polyethylene-terephthalate membranes; 2-polyethylene-terephthalate membranes; 3-airbags (gaps); 4-concrete mix; 5-deck panels; 6-support beams; 7-telescopic stands; 8-heat insulation; 9-infrared appliance; 10-shelter-tent. Note: Heat insulation (8) and the shelter-tent (10) are not required if the ambient temperature is above $+5{ }^{\circ} \mathrm{C}$.

The technology for the HT process is as follows:

Step 1. Installation of reflector lamps of 800 watts, which were used as infrared emitters, in such a way that the rays emitted by the reflector lamps were directed at the concrete surface. Each reflector lamp was used for an average of $1 \mathrm{~m}^{2}$ of surface. Reflector lamps can be installed in a metallic casing of $2 \times 2 \mathrm{~m}$ (hereinafter referred to as the "infrared appliance"). For HT, the effective distance between the surface of the infrared appliance and the concrete surface is recommended to be $1.2 \mathrm{~m}( \pm 15 \mathrm{~cm})$. At this step, the infrared appliance can be installed at a height of up to $3 \mathrm{~m}$.

Step 2. Laying and compacting concrete in the formwork of the structure. Formwork panels should be metallic for a better absorption of infrared rays.

Step 3. Cover the open surface of the laid and compacted concrete mix of the structure with three layers of polyethylene-terephthalate membrane with a transparent coefficient of 0.86 to form two airbags. The height between the concrete surface and the cover should not exceed 3-5 mm. Three layers of transparent material for infrared rays, installed with gaps between them and tightened on the 20-30-mm-thick frames, allow one to create closed air chambers between the layers and reduce the effect of outside air on the temperature of the laid concrete mix. The closed air space between the layers of transparent materials serves as a heat insulator from outside air, as well as preventing the outflow of heat and the evaporation of moisture from the concrete mix into the atmosphere. The polyethylene-terephthalate membranes with a transparent coefficient of 0.86 , which allow the infrared rays to pass, perceive the thermal energy of the infrared spectrum.

Step 4. Lower the infrared appliance to a height of $1.2 \mathrm{~m}( \pm 15 \mathrm{~cm})$ from the concrete surface, and then turn on the reflector lamps.

Step 5. HT of the laid and compacted concrete mix of the structure at a temperature of $80-95^{\circ} \mathrm{C}$ for $8 \mathrm{~h}$, followed by turning off the reflector lamps. 
The study showed that the strength of concrete after eight hours of HT was about $50-60 \%$ of the designed strength. Keeping polyethylene-terephthalate membranes for one or two days, depending on the ambient temperature, was recommended. After turning off the reflector lamps, the concrete continued to gain a strength close to the designed value $\left(80-100 \%\right.$ of $\left.R_{28}\right)$.

The formwork can be removed from the structure immediately after one day of concreting, which significantly reduces the formwork turnover cycle and the volume of formwork sets, thus shortening the construction period and leading to lower construction costs.

HT, using infrared rays, is possible both for the open surface of concrete (such as slabs) and through the formwork of concrete structures (such as walls).

Calculations show that the estimated electricity consumption for HT of $1 \mathrm{~m}^{3}$ of structures with BF-reinforced ECC using infrared emitters with reflector lamps of 800 watts and two-chamber airbags of polyethylene-terephthalate membranes is $95-120 \mathrm{kWh}$. At the same time, the cost of heating one cubic meter of concrete mix in the traditional way is $150-160 \mathrm{kWh}$.

This technology was recommended for HT of structures with BF-reinforced ECC where the thickness of the structure was up to $60 \mathrm{~cm}$.

\section{Materials and Methods}

Despite the great care taken in making specimens in laboratory studies, it cannot be claimed that all specimens were the same. In this study, an equal-making process has been done for the specimens in all the tests in order to minimize differences.

\subsection{Materials}

In accordance with the plan of the experimental study, after the preliminary experiments the following materials were used to make specimens of ECC with an increased compressive strength:

- $\quad$ Lightweight Expanded Clay Aggregate (LECA) with fractions of $5-10 \mathrm{~mm}=200 \mathrm{~kg} / \mathrm{m}^{3}$ was used as the coarse aggregate;

- Silica sand with a fineness modulus of $2.7=585 \mathrm{~kg} / \mathrm{m}^{3}$ was used as the fine aggregate;

- Silica powder of $50 \mu \mathrm{m}=100 \mathrm{~kg} / \mathrm{m}^{3}$ was used as a mineral filler;

- Portland cement CEM I $42.5 \mathrm{~N}=500 \mathrm{~kg} / \mathrm{m}^{3}$ was used as a binder;

- $\quad$ Microsilica $=62.5 \mathrm{~kg} / \mathrm{m}^{3}$ and fly ash $=62.5 \mathrm{~kg} / \mathrm{m}^{3}$ were used as the mineral additives;

- SikaPlast ${ }^{\circledR}$ Concrete in liquid form $=8 \mathrm{~L} / \mathrm{m}^{3}$ was used as a superplasticizing admixture;

- $\quad$ Tap water $=255 \mathrm{~L} / \mathrm{m}^{3}$ was used for mixing.

Portland cement CEM I $42.5 \mathrm{~N}$ is the most widely used one in Russia for monolithic construction. In addition, the use of this cement, both in lightweight concrete and fiber-reinforced one, shows fairly stable characteristics [1-3]. The relatively high consumption of cement makes it possible to obtain lightweight concrete with excellent mechanical properties, which makes it possible to use it both for bearing and enclosing structures.

Four different mixes of ECC were accepted for this study, containing the above mixes and the chopped BF with a thickness ( $\mathrm{t}$ ) of $15 \mu \mathrm{m}$ and length (l) of $20 \mathrm{~mm}$ in ratios of 1:0, 1:0.0045, 1:0.009 and 1:0.012 by weight of cement. As was proven earlier, the specified dosage range allows one to achieve a uniform distribution of fibers in the mixture and to obtain increased values of flexural strength and impact viscosity $[3,8,9,13]$.

The ratio of the length to thickness $(1 / t)$ of $B F$ used in the present study is 1333.333 . Figure 2 shows the chopped BF used in this study.

LECA, used in this study, was obtained from the LECA Production Plant "Keramzit", Serpukhov District, Moscow Region, Russia. Table 1 presents the physical properties and sieve analysis of LECA used in this study. 


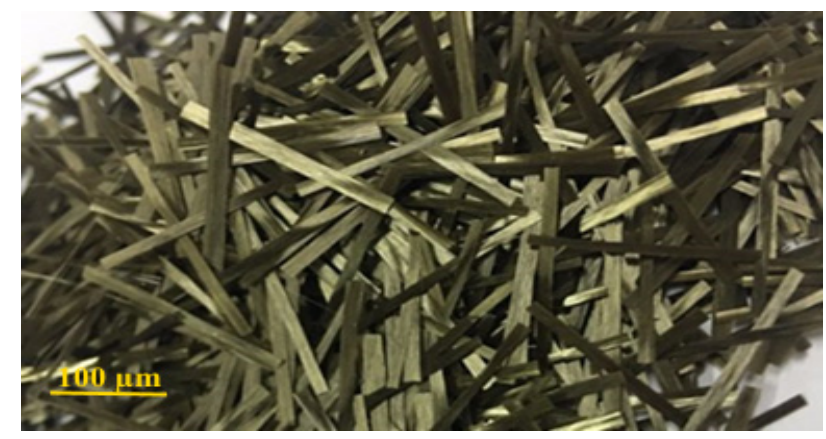

Figure 2. Chopped BF.

Table 1. Physical properties and sieve analysis of LECA.

\begin{tabular}{cc}
\hline Physical Property & Value \\
\hline Specific gravity & 0.69 \\
Fineness modulus & 5.93 \\
Bulk density (compacted), $\left[\mathrm{kg} / \mathrm{m}^{3}\right]$ & 278 \\
Water absorption $(24 \mathrm{~h}),[\%]$ & 26.4 \\
\hline Sieve Analysis, $[\mathrm{mm}]$ & Cumulative Percent by Weight Passing \\
\hline 10.0 & 90.4 \\
8.0 & 5.7 \\
5.0 & 3.9 \\
3.0 & 0 \\
\hline
\end{tabular}

LECA was preimmersed in the water for $24 \mathrm{~h}$ before mixing, and was then placed on a sieve for $2 \mathrm{~h}$ to dry off the water in order to reach an almost saturated surface dry condition. Figure 3 shows LECA used in this study as the coarse aggregate.

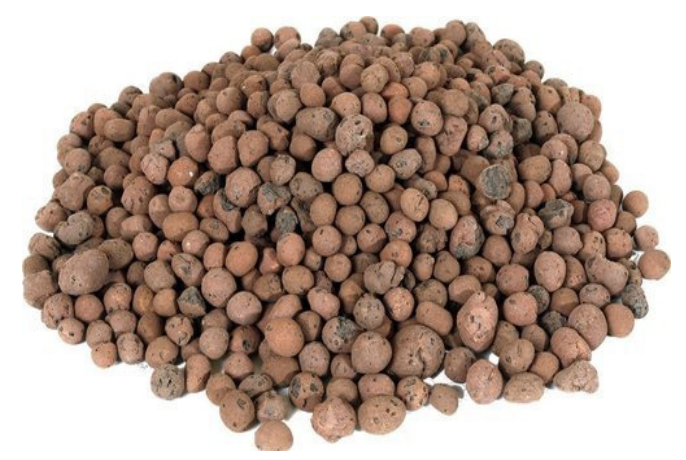

Figure 3. LECA as the coarse aggregate.

Silica sand and silica powder, used in the present study, were obtained from the Quarry Plant "Tyutchevo", Naro-Fominsky District, Moscow Region, Russia. Furthermore, Portland cement CEM I $42.5 \mathrm{~N}$, microsilica and fly ash were obtained from the Maltsovsky Cement Plant, Fokino District, Bryansk Region, Russia.

Tables 2 and 3 show the physical properties of silica sand and the chemical compositions of silica flour, Portland cement, microsilica and fly ash, respectively. 
Table 2. Physical properties of silica sand.

\begin{tabular}{cc}
\hline Physical Property & Value \\
\hline Grain size, [mm] & $0.5-1.0$ \\
Bulk density (compacted), $\left[\mathrm{kg} / \mathrm{m}^{3}\right]$ & 1430 \\
Hardness (on the Mohs scale) & 7 \\
Crushability & 0.3 \\
Humidity, [\%] & 1.7 \\
\hline
\end{tabular}

Table 3. Chemical compositions of silica flour, Portland cement, microsilica and fly ash in percentages (\%).

\begin{tabular}{|c|c|c|c|c|c|c|c|c|c|c|c|}
\hline $\begin{array}{l}\text { Chemical } \\
\text { Oxides, \% }\end{array}$ & $\mathrm{SiO}_{2}$ & $\mathrm{Al}_{2} \mathrm{O}_{3}$ & $\mathrm{Fe}_{2} \mathrm{O}_{3}$ & $\mathrm{~K}_{2} \mathrm{O}$ & $\mathrm{CaO}$ & $\mathrm{MgO}$ & $\mathrm{SO}_{3}$ & $\mathrm{P}_{2} \mathrm{O}_{5}$ & $\mathrm{TiO}$ & $\mathrm{MnO}$ & $\mathrm{Na}_{2} \mathrm{O}$ \\
\hline $\begin{array}{c}\text { Silica } \\
\text { powder }\end{array}$ & 99.63 & 0.23 & 0.12 & - & 0.02 & - & - & - & - & - & - \\
\hline $\begin{array}{c}\text { Portland } \\
\text { cement }\end{array}$ & 21.90 & 4.86 & 3.3 & 0.56 & 65.77 & 1.15 & 2.1 & - & - & - & 0.36 \\
\hline Microsilica & 98.77 & 0.23 & 0.07 & 0.26 & 0.31 & 0.04 & 0.17 & - & - & - & 0.15 \\
\hline Fly Ash & 66.24 & 19.81 & 6.41 & 1.39 & 3.13 & 1.21 & - & 0.36 & 0.86 & 0.05 & 0.54 \\
\hline
\end{tabular}

SikaPlast ${ }^{\circledR}$ Concrete, used in this study as the superplasticizing admixture, is a brown color aqueous solution of modified polycarboxylate esters and lignosulfonates.

The chopped BF, used in this study, was obtained from the BF Manufacturing Plant "Russkiy Bazalt", Chelyabinsk, Russia. Table 4 presents the chemical compositions of the chopped BF.

Table 4. Chemical compositions of chopped BF.

\begin{tabular}{ccccccccc}
\hline Chemical Oxides & $\mathrm{SiO}_{2}$ & $\mathrm{Al}_{2} \mathrm{O}_{3}$ & $\mathrm{FeO}+\mathrm{Fe}_{2} \mathrm{O}_{3}$ & $\mathrm{Na}_{2} \mathrm{O}+\mathrm{K}_{2} \mathrm{O}$ & $\mathrm{CaO}$ & $\mathbf{M g O}$ & $\mathrm{TiO}_{2}$ & Others \\
\hline Percentage (\%) & 57.3 & 15.4 & 11.7 & 1.9 & 7.3 & 4.1 & 1.6 & 0.7 \\
\hline
\end{tabular}

\subsection{Specimen Making and Research Method}

In order to study the issue of the strength growth of BF-reinforced ECC during HT, a standard method for strength determination using reference specimens, based on the Russian Standard GOST 10180-2012 [35], was considered in the present research. Thus, all powdery materials, the silica powder, the Portland cement, the microsilica and the fly ash were thoroughly mixed in a cement mixer until a uniform color was obtained, after which silica sand and LECA were mixed with the obtained powdery mixture. Liquid materials, the SikaPlast ${ }^{\circledR}$ Concrete and the water were mixed in a separate container. This liquid substance was then added to the dry mixture and thoroughly mixed in the same cement mixer until a smooth mixture was obtained. To make BF-reinforced ECC, chopped BFs were added to the dry mixture.

In accordance with the plan of the experiment, a total of four series of ECC test specimens and one series of controlled specimens were made with dimensions of $100 \times 100 \times 100 \mathrm{~mm}$, containing the stated compositions and BF in ratios of 1:0, 1:0.0045, 1:0.009 and 1:0.012 by weight. A total of 540 ECC specimens were made (five ECC specimens for each test).

60 ECC specimens and the control specimens were cured in an air-humid condition in wet sawdust at a room temperature of $19-22^{\circ} \mathrm{C}$, and they were tested at the curing periods of 7,14 and 28 days.

120 ECC test specimens in each series (a total of 480 test specimens) were covered with three layers of polyethylene-terephthalate membrane (two-chamber closed airbags) after $1.5 \mathrm{~h}$ of setting, and HT was carried out by infrared rays for $7,9,11,13,16$ and $24 \mathrm{~h}$. Then, the heat-treated specimens were tested for compressive strength after $0.5,4,12$ and $24 \mathrm{~h}$ cooling periods. 
Reflector lamps of $800 \mathrm{~W}$ were used as infrared emitters. Infrared heating of the ECC specimens was carried out in natural conditions in cloudy weather at an ambient air temperature of +5 to $+12{ }^{\circ} \mathrm{C}$ and a wind speed of 3 to $9 \mathrm{~m} / \mathrm{s}$.

As has already been noted, one of the features of HT technology for laid and compacted concrete mixes with infrared rays is the necessity to create conditions that prevent a moisture loss from the concrete during the process of strength growth during its heating and under the influence of wind, which causes intense dehydration. To exclude this circumstance and to increase the efficiency of the infrared heating of the concrete, three layers of transparent material for infrared rays are tightly installed next to each other, without gaps, on the open surface of the laid and compacted concrete mix.

Transparent material transmits infrared rays from emitters directed toward the surface of the laid and compacted concrete mix. The energy of the infrared spectrum is converted into heat on the absorbing surface and spreads through the thickness of the concrete mix.

Three layers of polyethylene-terephthalate membranes with a transparent coefficient of 0.86 for receiving infrared rays, installed with gaps between them and tightened on a frame, allowed for the creation of closed air chambers between the layers and reduced the effect of outside air on the temperature of the ECC specimens. A closed air space between layers of transparent materials serves as a heat insulator from outside air and prevents the outflow of heat and water vapor from ECC specimens to the atmosphere. Furthermore, the transparent screen, which allows the infrared rays to pass, perceives the thermal energy of the infrared spectrum.

The distance between the reflector lamp and the surface of the ECC specimens was $1.2 \mathrm{~m}( \pm 15 \mathrm{~cm})$.

The temperature in the ECC specimens was measured by thermocouples and recorded on coordinate tapes of the automatic recording device KSP-4A. The temperature on the surfaces of the ECC specimens under transparent screens was maintained at $85 \pm 3{ }^{\circ} \mathrm{C}$.

The study of the compressive strength of the ECC specimens was conducted on a hydraulic press of $1500 \mathrm{kN}$.

The research was carried out based on analyzing, generalizing and evaluations of experimental data. Mathematical processing of experimental data was carried out based on probability theory and mathematical statistics [36,37]. The patterns of changes in the compressive strength were established using a regression analysis. The analyzed data were verified by Spearman's independence criterion and Wilcoxon homogeneity test [36,37], while ensuring $\alpha \approx 0.95$.

\section{Results and Discussion}

As part of this study, the experimental determination of the compressive strength of ECC specimens was carried out. The results of the laboratory tests of the control ECC specimens are shown in Table 5. Each average value of compressive strength in Table 5 was calculated according to the test results of five specimens. The standard deviations of the test data ranged from 0.53 to 0.72 .

Table 5. Results of laboratory tests of control ECC specimens on compressive strength.

\begin{tabular}{ccccc}
\hline \multirow{2}{*}{$\begin{array}{c}\text { Curing Period, } \\
\text { [Days] }\end{array}$} & \multicolumn{4}{c}{$\begin{array}{c}\text { Average Compressive Strength, } \boldsymbol{R}_{\boldsymbol{c}} \text { [MPa] } \\
\text { with Standard Deviation of Test Data }\end{array}$} \\
\cline { 2 - 4 } & $\mathbf{0 \%}$ BF & $\mathbf{0 . 4 5 \% ~ B F}$ & $\mathbf{0 . 9 \%}$ BF & $\mathbf{1 . 2 \%}$ BF \\
\hline 7 & $14.16(0.62)$ & $15.86(0.53)$ & $18.25(0.72)$ & $20.19(0.61)$ \\
14 & $19.79(0.54)$ & $21.59(0.66)$ & $24.97(0.63)$ & $27.77(0.71)$ \\
28 & $22.53(0.69)$ & $25.12(0.57)$ & $28.50(0.68)$ & $31.92(0.59)$ \\
\hline
\end{tabular}

Note: the standard deviations of the test data are shown in round brackets.

Figure 4 shows the diagrams of changes in compressive strength of the control ECC specimens, the specimens that were tested without HT, depending on the curing period based on Table 5 . The fitting curve is shown as a black line. 


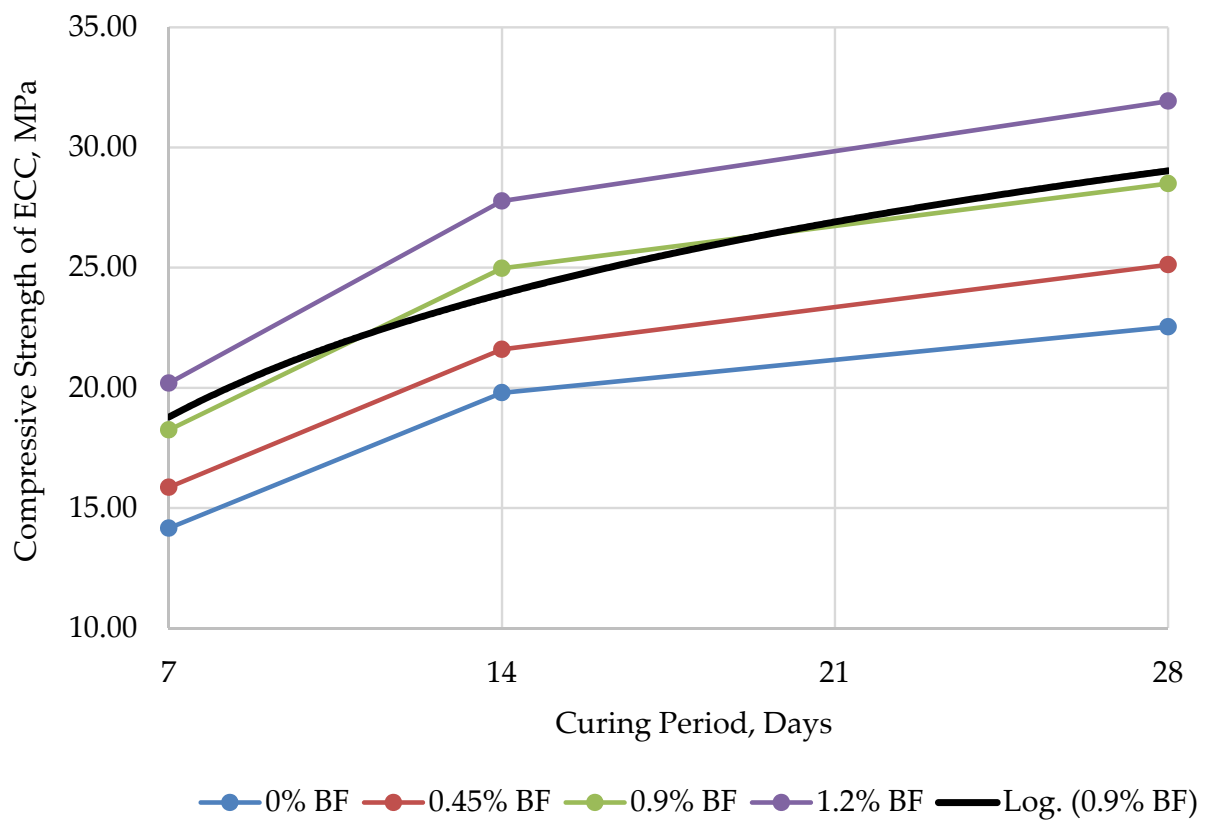

Figure 4. Compressive strength of control ECC specimens depending on the curing period (the fitting curve is shown as a black line).

Based on the experimental study of the control ECC specimens (Table 5 and Figure 4), it can be concluded that BF works well with ECC, i.e., increments in the quantity of BF added to ECC led to an increase in the compressive strength. These experimental data are in good agreement with the results published earlier [1,2,12].

The results also showed that in seven days of curing the compressive strength could reach about $60 \%$ of the compressive strength after a 28-day curing period, regardless of whether ECC was with BF or without $\mathrm{BF}$.

Figure 5 shows the dependency of the compressive strength of the control ECC specimens, the specimens that were tested without $\mathrm{HT}$, on the curing period and the proportion of BF.

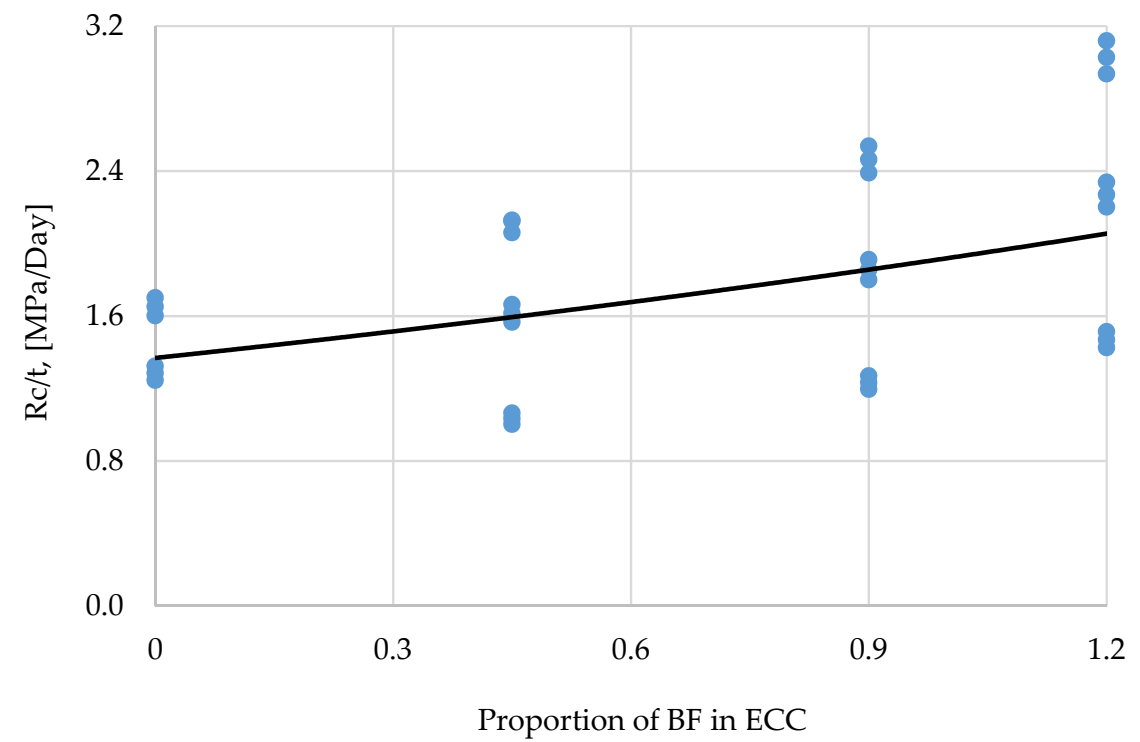

Figure 5. Dependency of the compressive strength of ECC depending on the percentage of BF and the curing period. 
Based on the analytical data of the compressive strength of the control ECC specimens, the specimens that were tested without HT (Table 5, Figures 4 and 5), and using probability theory and mathematical statistics [36,37], a mathematical model for determining the compressive strength of ECC depending on the proportion of BF in ECC and the curing period was developed:

$$
R_{c}=R_{c}^{t}+\left[\frac{1.245 \cdot t \cdot e^{45 \cdot F}}{e^{45 \cdot F}+\frac{e^{45 \cdot F}}{t_{F}}}\right]
$$

where $R_{c}$-compressive strength of ECC, [MPa]; $R_{c}^{t}$-compressive strength of ECC (without $\mathrm{BF}$ ) of the corresponding grade on the day of determination, [MPa]; 1.245-coefficient of compressive strength changes of ECC with BF over the period, [MPa/Day]; $e$-exponential function, $e \approx 2.71828$; $F$-proportion of BF in ECC, in relative units; $t$-curing period, [Days] ( $t \leq 28$ days); and $t_{F}$-exposure of $\mathrm{BF}$ in $\mathrm{ECC}, t_{F}=t$ without unit.

Note: the part in square brackets is for BF-reinforced ECC. If ECC is without BF, the compressive strength of ECC should be calculated in accordance with available USA, European, Russian or any other approved standard.

It is advisable to use the proposed model (Equation (1)) to apply an assessment of the compressive strength of BF-reinforced ECC, as it has an accuracy of $\pm 4-5 \%$ and a determination coefficient of $\mathrm{R}^{2}=0.926$. It allows for the determination of the permissible load on specimens that are curing under normal air-humid conditions. These data are in good agreement with the results published earlier $[1,2,12]$.

HT of BF-reinforced ECC significantly accelerates the strength growth during cast-in-situ construction, which allows for a reduction in the turnover of the formwork and the construction period, and which leads to lower construction costs. The results of the laboratory tests of heat-treated ECC specimens on compressive strength are shown in Table 6.

The experimental study of heat-treated ECC specimens (Table 6) showed that HT using infrared rays allowed one to obtain more than $60 \%$ of the designed strength (in accordance with the tests on the controlled ECC specimens) in $9 \mathrm{~h}$ and about $75 \%$ in $24 \mathrm{~h}$, regardless of whether ECC was with BF or without BF.

The most important feature in understanding the relationship between normal air-humid curing of concrete and HT of concrete is the determination of the relative strength, which is calculated by the formula $[15,16]$ :

$$
R_{\mathrm{R}}=\frac{R_{\mathrm{HT}}}{R_{28}}
$$

where $R_{\mathrm{R}}$-relative strength, in relative units; $R_{\mathrm{HT}}$ —compressive strength of concrete after HT, [MPa]; and $R_{28}$-designed compressive strength of concrete [MPa].

Using Equation (2), the calculated data of the relative strength of ECC specimens at different periods of HT are shown in Table 7. The designed compressive strengths of ECC specimens $\left(R_{28}\right)$ were taken from Table 5 at a curing period of 28 days (at $0 \% \mathrm{BF}, R_{28}=22.53 \mathrm{MPa}$; at $0.45 \% \mathrm{BF}$, $R_{28}=25.12 \mathrm{MPa}$; at $0.9 \% \mathrm{BF}, R_{28}=28.50 \mathrm{MPa}$; at $1.2 \% \mathrm{BF}, R_{28}=31.92 \mathrm{MPa}$ ), and the compressive strengths of ECC specimens $\left(R_{\mathrm{HT}}\right)$ after HT were taken from Table 6 . Table 8 presents the average relative strength of ECC specimens at different periods of HT. 
Table 6. Results of laboratory tests of heat-treated ECC specimens on compressive strength.

\begin{tabular}{|c|c|c|c|c|}
\hline \multirow{2}{*}{$\begin{array}{l}\text { Period of HT, } \\
\text { [Hours] }\end{array}$} & \multicolumn{4}{|c|}{$\begin{array}{c}\text { Average Compressive Strength depending on Cooling Period, } R_{\mathrm{HT}}[\mathrm{MPa}] \\
\text { with Standard Deviation of Test Data }\end{array}$} \\
\hline & $0.5 \mathrm{~h}$ & $4 \mathrm{~h}$ & $12 \mathrm{~h}$ & $24 \mathrm{~h}$ \\
\hline \multicolumn{5}{|c|}{ Heat-Treated ECC Specimens with 0\% BF } \\
\hline 7 & $09.69(0.71)$ & $11.27(0.68)$ & $11.94(0.49)$ & $12.39(0.72)$ \\
\hline 9 & $11.72(0.67)$ & $12.84(0.73)$ & $13.52(0.66)$ & $14.20(0.54)$ \\
\hline 11 & $12.83(0.65)$ & $13.97(0.61)$ & $14.65(0.67)$ & $15.32(0.59)$ \\
\hline 13 & $13.75(0.59)$ & $14.64(0.58)$ & $15.55(0.57)$ & $16.00(0.68)$ \\
\hline 16 & $14.65(0.69)$ & $15.32(0.69)$ & $15.94(0.70)$ & $16.45(0.58)$ \\
\hline 24 & $15.10(0.74)$ & $15.77(0.68)$ & $16.42(0.64)$ & $16.90(0.55)$ \\
\hline \multicolumn{5}{|c|}{ Heat-Treated ECC Specimens with $0.45 \%$ BF } \\
\hline 7 & $10.80(0.61)$ & $12.56(0.70)$ & $13.31(0.67)$ & $13.82(0.54)$ \\
\hline 9 & $13.06(0.49)$ & $14.32(0.58)$ & $15.07(0.58)$ & $15.83(0.69)$ \\
\hline 11 & $14.31(0.66)$ & $15.58(0.54)$ & $16.32(0.59)$ & $17.08(0.65)$ \\
\hline 13 & $15.32(0.53)$ & $16.33(0.69)$ & $17.33(0.70)$ & $17.84(0.68)$ \\
\hline 16 & $16.32(0.57)$ & $17.07(0.71)$ & $17.83(0.58)$ & $18.34(0.72)$ \\
\hline 24 & $16.83(0.68)$ & $17.58(0.56)$ & $18.33(0.68)$ & $18.84(0.59)$ \\
\hline \multicolumn{5}{|c|}{ Heat-Treated ECC Specimens with $0.9 \%$ BF } \\
\hline 7 & $12.25(0.58)$ & $14.25(0.72)$ & $15.10(0.71)$ & $15.67(0.69)$ \\
\hline 9 & $14.82(0.70)$ & $16.24(0.53)$ & $17.09(0.67)$ & $17.95(0.61)$ \\
\hline 11 & $16.22(0.71)$ & $17.69(0.57)$ & $18.52(0.65)$ & $19.38(0.70)$ \\
\hline 13 & $17.38(0.63)$ & $18.50(0.68)$ & $19.66(0.69)$ & $20.23(0.52)$ \\
\hline 16 & $18.52(0.57)$ & $19.37(0.49)$ & $20.19(0.70)$ & $20.80(0.63)$ \\
\hline 24 & $19.09(0.70)$ & $19.94(0.59)$ & $20.77(0.68)$ & $21.37(0.57)$ \\
\hline \multicolumn{5}{|c|}{ Heat-Treated ECC Specimens with $1.2 \%$ BF } \\
\hline 7 & $13.73(0.49)$ & $15.96(0.63)$ & $16.92(0.67)$ & $17.56(0.54)$ \\
\hline 9 & $16.60(0.70)$ & $18.20(0.69)$ & $19.16(0.58)$ & $20.11(0.72)$ \\
\hline 11 & $18.17(0.71)$ & $19.79(0.57)$ & $20.75(0.51)$ & $21.71(0.71)$ \\
\hline 13 & $19.47(0.53)$ & $20.71(0.66)$ & $22.03(0.54)$ & $22.67(0.63)$ \\
\hline 16 & $20.72(0.68)$ & $21.71(0.70)$ & $22.62(0.59)$ & $23.30(0.53)$ \\
\hline 24 & $21.39(0.62)$ & $22.35(0.51)$ & $23.27(0.66)$ & $23.94(0.57)$ \\
\hline
\end{tabular}

Note: the standard deviations of the test data are shown in round brackets.

After processing the experimental data of Table 8, the diagrams of changes in the relative strength of BF-reinforced ECC at different cooling periods depending on the period of HT (Figure 6) were obtained. In order to make the relative strength $\left(R_{R}\right)$ more comprehensible in the diagrams, the unit of relative strength is shown in percentages. The fitting curve of the diagrams is shown as a black line. 
Table 7. Calculated data of the relative strength of BF-reinforced ECC specimens at different periods of HT.

\begin{tabular}{|c|c|c|c|c|}
\hline \multirow{2}{*}{$\begin{array}{l}\text { Period of HT, } \\
\text { [Hours] }\end{array}$} & \multicolumn{4}{|c|}{ Relative Strength of ECC at Different Cooling Periods } \\
\hline & $0.5 \mathrm{~h}$ & $4 \mathrm{~h}$ & $12 \mathrm{~h}$ & $24 \mathrm{~h}$ \\
\hline \multicolumn{5}{|c|}{ Heat-Treated ECC Specimens with 0\% BF } \\
\hline 7 & 0.4301 & 0.5002 & 0.5299 & 0.5499 \\
\hline 9 & 0.5202 & 0.5699 & 0.6001 & 0.6303 \\
\hline 11 & 0.5634 & 0.6201 & 0.6502 & 0.6799 \\
\hline 13 & 0.6013 & 0.6498 & 0.6702 & 0.7102 \\
\hline 16 & 0.6412 & 0.6799 & 0.7085 & 0.7301 \\
\hline 24 & 0.6621 & 0.6999 & 0.7288 & 0.7501 \\
\hline \multicolumn{5}{|c|}{ Heat-Treated ECC Specimens with $0.45 \%$ BF } \\
\hline 7 & 0.4309 & 0.5001 & 0.5304 & 0.5502 \\
\hline 9 & 0.5199 & 0.5707 & 0.5999 & 0.6299 \\
\hline 11 & 0.5596 & 0.6203 & 0.6498 & 0.6818 \\
\hline 13 & 0.6026 & 0.6501 & 0.6746 & 0.7113 \\
\hline 16 & 0.6406 & 0.6814 & 0.7098 & 0.7309 \\
\hline 24 & 0.6609 & 0.7021 & 0.7304 & 0.7498 \\
\hline \multicolumn{5}{|c|}{ Heat-Treated ECC Specimens with $0.9 \%$ BF } \\
\hline 7 & 0.4298 & 0.4998 & 0.5298 & 0.5499 \\
\hline 9 & 0.5201 & 0.5702 & 0.5997 & 0.6308 \\
\hline 11 & 0.5611 & 0.6207 & 0.6501 & 0.6802 \\
\hline 13 & 0.6018 & 0.6493 & 0.6718 & 0.7098 \\
\hline 16 & 0.6409 & 0.6797 & 0.7104 & 0.7298 \\
\hline 24 & 0.6618 & 0.6999 & 0.7288 & 0.7509 \\
\hline \multicolumn{5}{|c|}{ Heat-Treated ECC Specimens with $1.2 \%$ BF } \\
\hline 7 & 0.4302 & 0.5012 & 0.5307 & 0.5506 \\
\hline 9 & 0.5213 & 0.5708 & 0.6003 & 0.6314 \\
\hline 11 & 0.5629 & 0.6199 & 0.6501 & 0.6817 \\
\hline 13 & 0.6094 & 0.6488 & 0.6743 & 0.7108 \\
\hline 16 & 0.6428 & 0.6802 & 0.7089 & 0.7304 \\
\hline 24 & 0.6609 & 0.7024 & 0.7296 & 0.7518 \\
\hline
\end{tabular}

Table 8. Average relative strength of BF-reinforced ECC specimens at different periods of HT (based on Table 7).

\begin{tabular}{ccccc}
\hline \multirow{2}{*}{$\begin{array}{c}\text { Period of HT } \\
\text { [Hours] }\end{array}$} & \multicolumn{4}{c}{$\begin{array}{c}\text { Average Relative Strength of ECC at Different Cooling Periods } \\
\text { (Standard Deviation of Test Data) }\end{array}$} \\
\cline { 2 - 5 } & $\mathbf{0 . 5} \mathbf{~ h}$ & $\mathbf{4} \mathbf{h}$ & $\mathbf{1 2} \mathbf{~ h}$ & $\mathbf{2 4} \mathbf{~ h}$ \\
\hline 7 & $0.43(0.57)$ & $0.50(0.72)$ & $0.53(0.71)$ & $0.55(0.69)$ \\
\hline 9 & $0.52(0.74)$ & $0.57(0.69)$ & $0.60(0.51)$ & $0.63(0.57)$ \\
\hline 11 & $0.56(0.58)$ & $0.62(0.48)$ & $0.65(0.66)$ & $0.68(0.67)$ \\
\hline 13 & $0.60(0.71)$ & $0.65(0.52)$ & $0.67(0.57)$ & $0.71(0.49)$ \\
\hline 16 & $0.64(0.68)$ & $0.68(0.58)$ & $0.71(0.59)$ & $0.73(0.63)$ \\
\hline 24 & $0.66(0.72)$ & $0.70(0.67)$ & $0.73(0.52)$ & $0.75(0.52)$ \\
\hline
\end{tabular}

Note: the standard deviations of the data are shown in round brackets. 


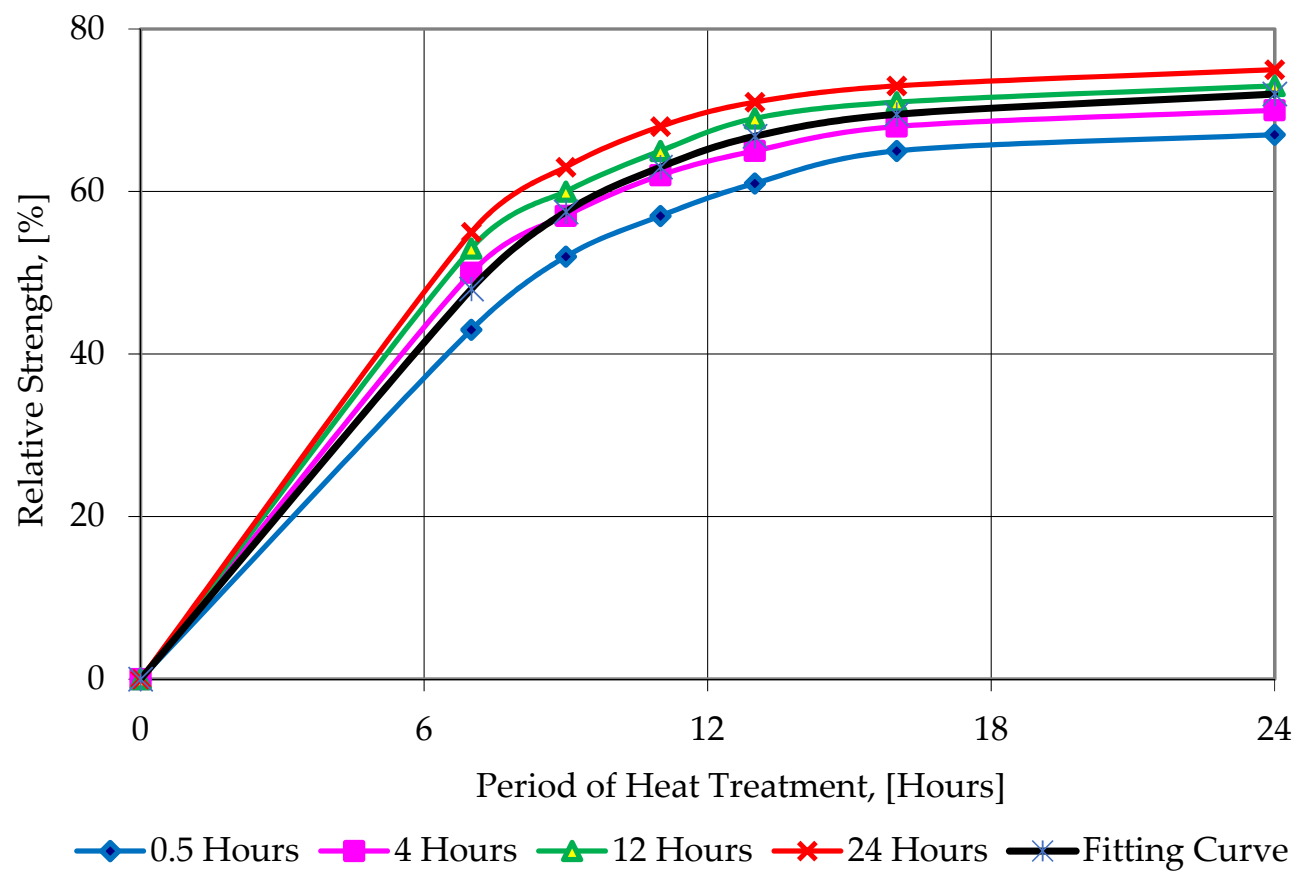

Figure 6. Changes in the relative strength of heat-treated BF-reinforced ECC depending on the period of HT.

Based on analytical data (Figure 6), using probability theory and mathematical statistics, refs. $[29,30]$, a mathematical model for determining the compressive strength of BF-reinforced ECC after HT was developed:

$$
R_{E C C}=R_{28}\left[\frac{t_{H T}\left(12+0.27 t_{t}\right)}{1+\frac{t_{H T}\left(12+0.27 t_{t}\right)}{100}}\right]
$$

where $R_{\mathrm{ECC}}$ - compressive strength of BF-reinforced ECC after $\mathrm{HT}$, [MPa]; $R_{28}$-designed compressive strength of BF-reinforced ECC, [MPa]; $t_{H T}$-period of HT, [Hours]; and $t_{t}$-cooling time elapsed after HT, [Hours].

The proposed mathematical model allows one to forecast the compressive strength of ECC after HT depending on the period of HT and the cooling time, with an accuracy of $\pm 3-4 \%$ and a determination coefficient of $R^{2}=0.953$.

The experimental study of the said HT technology using infrared rays and a two-chamber polyethylene-terephthalate membrane cover showed its efficiency during cast-in-situ construction in the cold season when HT was required for a laid and compacted concrete mix to create favorable conditions for chemical reactions during its curing.

\section{Conclusions}

Based on the present study, it can be concluded that BF works well with ECC, i.e., increments in the quantity of BF added to ECC led to an increase in mechanical properties.

The proposed mathematical model for determining the compressive strength of BF-reinforced ECC, depending on the proportion of BF in ECC and the curing period (Equation (1)), allows for a determination of the permissible load on BF-reinforced ECC structures, which cure under normal air-humid conditions, during construction works.

The proposed HT technology can be used for mass cast-in-situ construction in any season, which significantly reduces the formwork turnover cycle and the volume of formwork sets, thus shortening the construction period and leading to lower construction costs.

Three layers of polyethylene-terephthalate membrane, as a transparent material with a coefficient of 0.86 , allow for an effective heating of the entire surface of the concrete mix, as well as preventing 
the dehydration of the concrete mix during its HT. The effective distance between the surface of the infrared appliance and the concrete surface is $1.2 \mathrm{~m}( \pm 15 \mathrm{~cm})$.

For $1 \mathrm{~m}^{3}$ of structures with BF-reinforced ECC, the estimated electricity consumption of HT using infrared emitters with reflector lamps of 800 watts and two-chamber airbags is $95-120 \mathrm{kWh}$.

The proposed mathematical model for determining the compressive strength of ECC after HT (Equation (3)) allows one to forecast the strength growth of ECC in a real cast-in-situ construction immediately after curing with HT.

The experimental study of the mentioned HT technology, using infrared rays and a two-chamber polyethylene-terephthalate membrane cover, showed its efficiency in cast-in-situ construction during the cold season when HT is required for laid and compacted concrete mixes in order to create favorable conditions for chemical reactions during their curing.

Author Contributions: Conceptualization, M.K. and D.K.; methodology, P.C.C. and D.K.; validation, P.C.C. and D.K.; formal analysis, R.F. and S.K.; investigation, M.K. and D.K.; resources, R.F., S.K. and N.A.; writing-original draft preparation, M.K., N.V. and D.K.; writing-review and editing, R.F. and N.A.; visualization, R.F. and A.O.; supervision, M.K., N.V. and D.K.; project administration, M.K. and D.K.; funding acquisition, R.F. and A.O. All authors have read and agreed to the published version of the manuscript.

Funding: Funding for open access charge: Peter the Great St. Petersburg Polytechnic University, Russian Academic Excellence Project «5-100».

Conflicts of Interest: The authors declare no conflict of interest.

\section{References}

1. Real, S.; Gomes, M.G.; Rodrigues, A.M.; Bogas, J.A. Contribution of structural lightweight aggregate concrete to the reduction of thermal bridging effect in buildings. Constr. Build. Mater. 2016, 121, 460-470. [CrossRef]

2. Vijayalakshmi, R.; Ramanagopal, S. Structural concrete using expanded clay aggregate: A review. Indian J. Sci. Technol. 2018, 11, 1-12. [CrossRef]

3. Klyuev, S.V.; Khezhev, T.A.; Pukharenko, Y.V.; Klyuev, A.V. To the question of fiber reinforcement of concrete. Mater. Sci. Forum 2018, 945, 25-29. [CrossRef]

4. Fediuk, R.S.; Lesovik, V.S.; Svintsov, A.P.; Mochalov, A.V.; Kulichkov, S.; Stoyushko, N.Y.; Gladkova, N.A.; Timokhin, R.A. Self-compacting concrete using pretreatmented rice husk ash. Mag. Civ. Eng. 2018, 79, 66-76.

5. Cherevatova, A.V.; Zhernovskaya, I.V.; Alehin, D.A.; Kozhukhova, M.I.; Kozhukhova, N.I.; Yakovlev, E.A. Theoretical aspects of development of composite nanostructured gypsum binder characterized by increased heat resistance. Constr. Mater. Prod. 2019, 2, 5-13.

6. Strokova, V.V.; Babaev, V.B.; Markov, A.Y.; Sobolev, K.G.; Nelyubova, V.V. Comparative evaluation of road pavement structures using cement concrete. Constr. Mater. Prod. 2019, 2, 56-63.

7. Abirami, T.; Loganaganandan, M.; Murali, G.; Fediuk, R.; Sreekrishna, R.V.; Vignesh, T.; Januppriya, G.; Karthikeyan, K. Experimental research on impact response of novel steel fibrous concretes under falling mass impact. Constr. Build. Mater. 2019, 222, 447-457. [CrossRef]

8. Klyuev, S.V.; Khezhev, T.A.; Pukharenko, Y.V.; Klyuev, A.V. Experimental study of fiber-reinforced concrete structures. Mater. Sci. Forum 2018, 945, 115-119. [CrossRef]

9. Fediuk, R.; Smoliakov, A.; Muraviov, A. Mechanical properties of fiber-reinforced concrete using composite binders. Adv. Mater. Sci. Eng. 2017, 2017, 2316347. [CrossRef]

10. Akhtyamova, L.S.; Sabitov, L.S.; Mailyan, A.L.; Mailyan, L.R.; Radaykin, O.V. Technological and design features of designing a modular reinforced concrete foundation for a high-rise building of various types. Constr. Mater. Prod. 2019, 2, 5-11.

11. Manzhilevskaya, S.E. Organizational and economic problems of ecological safety in construction. Constr. Mater. Prod. 2019, 2, 73-78.

12. Sun, X.; Gao, Z.; Cao, P.; Zhou, C. Mechanical properties tests and multiscale numerical simulations for basalt fiber reinforced concrete. Constr. Build. Mater. 2019, 202, 58-72. [CrossRef]

13. Fediuk, R. Reducing permeability of fiber concrete using composite binders. Spec. Top. Rev. Porous Media 2018, 9, 79-89. [CrossRef] 
14. Klyuev, S.V.; Klyuev, A.V.; Khezhev, T.A.; Pukharenko, Y.V. Technogenic sands as effective filler for fine-grained fibre concrete. J. Phys. Conf. Ser. 2018, 1118, 012020. [CrossRef]

15. Karagol, F.; Demirboga, R.; Kaygusuz, M.A.; Yadollahi, M.M.; Polat, R. The influence of calcium nitrate as antifreeze admixture on the compressive strength of concrete exposed to low temperatures. Cold Reg. Sci. Technol. 2013, 89, 30-35. [CrossRef]

16. Klyuev, S.V.; Klyuev, A.V.; Shorstova, E.S. The micro silicon additive effects on the fine-grassed concrete properties for 3-d additive technologies. Mater. Sci. Forum 2019, 974, 131-135. [CrossRef]

17. Fediuk, R.; Pak, A.; Kuzmin, D. Fine-Grained Concrete of Composite Binder. IOP Conf. Ser. Mater. Sci. Eng. 2017, 262, 012025. [CrossRef]

18. Polat, R. The effect of antifreeze additives on fresh concrete subjected to freezing and thawing cycles. Cold Reg. Sci. Technol. 2016, 127, 10-17. [CrossRef]

19. Dudin, M.O.; Vatin, N.I.; Barabanshchikov, Y.G. Modeling a set of concrete strength in the program ELCUT at warming of monolithic structures by wire. Mag. Civ. Eng. 2015, 54, 33-45. [CrossRef]

20. Nikolenko, Y.V.; Manaeva, M.M.; Stashevskaya, N.A. About the technology of concreting in cast-in-situ building construction. RUDN J. Eng. Res. 2014, 4, 84-89. Available online: https://elibrary.ru/item.asp?id= 22697370 (accessed on 29 October 2020).

21. Svintsov, A.P.; Nikolenko, Y.V.; Patrakhaltsev, N.N.; Ivanov, V.N. Improving the technology of concreting work in the cast-in-situ building construction. Constr. Mater. 2012, 1, 28-31. Available online: https: //elibrary.ru/item.asp?id=17337048 (accessed on 29 October 2020).

22. Fediuk, R.; Smoliakov, A.; Stoyushko, N. Increase in composite binder activity. IOP Conf. Ser. Mater. Sci. Eng. 2016, 156, 012042. [CrossRef]

23. Im, D.; Sancharoen, P.; Julnipitawong, P.; Tangtermsirikul, S. Effect of chloride and corrosion of reinforcing steel on thermal behavior of concrete and its modeling. Eng. J. 2018, 22, 143-163. [CrossRef]

24. Solovyanchik, A.R.; Shifrin, S.A.; Rudenko, A.E. Method for Concreting the Monolithic Structures with Elements of Different Massivity. Patent of the Russian Federation No. RU2143047C1, 1999. Available online: https://yandex.ru/patents/doc/RU2143047C1_19991220 (accessed on 29 October 2020).

25. Svintsov, A.P.; Svintsova, N.K.; Nikolenko, Y.V.; Gladchenko, L.K. The Device for Thermal Treatment of Concrete in Cast-In-Situ Structures. Patent of the Russian Federation No. RU113287U1, 2012. Available online: https://yandex.ru/patents/doc/RU113287U1_20120210 (accessed on 29 October 2020).

26. Fediuk, R.S.; Smoliakov, A.K.; Timokhin, R.A.; Batarshin, V.O.; Yevdokimova, Y.G. Using thermal power plants waste for building materials. IOP Conf. Ser. Earth Environ. Sci. 2018, 87, 092010. [CrossRef]

27. Yew, M.K.; Mahmud, H.; Ang, B.C.; Yew, M.C. Effects of heat treatment on oil palm shell coarse aggregates for high strength lightweight concrete. Mater. Des. 2014, 54, 702-707. [CrossRef]

28. Bumanis, G.; Toropovs, N.; Dembovska, L.; Bajare, D.; Korjakins, A. The effect of heat treatment on the properties of ultra high strength concrete. In Proceedings of the 10th International Scientific and Practical Conference, Rezekne, Latvia, 18-20 June 2015; pp. 22-27.

29. Pillai, C.S.; Santhakumar, A.R.; Chandrasekaran, S.; Viswanathan, S.; Mathiyarasu, R.; Kumar, J.A.; Preetha, R.; Venkatraman, B. Effect of heat treatment on neutron attenuation characteristics of high density concretes (HDC). Prog. Nucl. Energy 2016, 93, 76-83.

30. Derabla, R.; Benmalek, M.L. Characterization of heat-treated self-compacting concrete containing mineral admixtures at early age and in the long term. Constr. Build. Mater. 2014, 66, 787-794. [CrossRef]

31. Höhlig, B.; Schröfl, C.; Hempel, S.; Noack, I.; Mechtcherine, V.; Schmidt, D.; Trommler, U.; Roland, U. Heat treatment of fresh concrete by radio waves-Avoiding delayed ettringite formation. Constr. Build. Mater. 2017, 143, 580-588. [CrossRef]

32. Shui, Z.; Xuan, D.; Wan, H.; Cao, B. Rehydration reactivity of recycled mortar from concrete waste experienced to thermal treatment. Constr. Build. Mater. 2008, 22, 1723-1729. [CrossRef]

33. Pandurangan, K.; Dayanithy, A.; Prakash, S.O. Influence of treatment methods on the bond strength of recycled aggregate concrete. Constr. Build. Mater. 2016, 120, 212-221. [CrossRef]

34. Kharun, M.; Nikolenko, Y.V.; Stashevskaya, N.A.; Koroteev, D.D. Thermal treatment of self-compacting concrete in cast-in-situ construction. Key Eng. Mater. 2017, 753, 315-320. [CrossRef]

35. GOST 10180-2012. Concretes: Methods for Strength Determination Using Reference Specimens; Standartinform: Moscow, Russia, 2013; Available online: http://gostexpert.ru/gost/gost-10180-2012 (accessed on 29 October 2020). 
36. Gmurman, V.E. Theory of Probability and Mathematical Statistics, 9th ed.; Vysshaya Shkola: Moscow, Russia, 2009; Available online: http://lib.maupfib.kg/wp-content/uploads/2015/12/Teoria_veroatnosty_mat_stat.pdf (accessed on 29 October 2020).

37. Gmurman, V.E. A Guide to Solving Problems in Probability Theory and Mathematical Statistics, 10th ed.; Vysshaya Shkola: Moscow, Russia, 2004; Available online: http://orlovsky-mephi.ru/books/Probability/ GmurmanSolutions2004.pdf (accessed on 29 October 2020).

Publisher's Note: MDPI stays neutral with regard to jurisdictional claims in published maps and institutional affiliations.

(C) 2020 by the authors. Licensee MDPI, Basel, Switzerland. This article is an open access article distributed under the terms and conditions of the Creative Commons Attribution (CC BY) license (http://creativecommons.org/licenses/by/4.0/). 